原 著 論 文 $(1)$

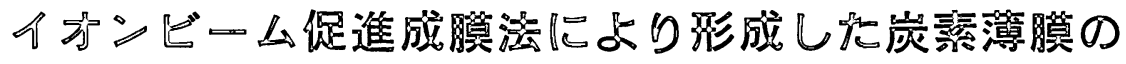

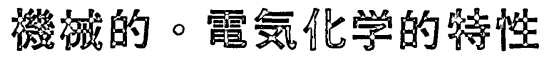

\author{
藤花隆宣 ${ }^{* 1,+}$ - 関口 敦*2 渡辺 博*3 高橋勝緒*4 岩木正哉*4 \\ *1 埼玉大学大学院理工学研究科 T338 埼玉県浦和市下大久保 255 \\ *2 東京理科大学理工学部 ₹278 千葉県野田市山崎 2641 \\ *3 学習院大学理学部 个171 東京都豊島区目白 1-5-1 \\ *4 理化学研究所 $\mathbf{T} 351-01$ 埼玉県和光市広沢 2-1
}

(1990年 12 月 19 日 受理)

\section{Mechanical and Electrochemical Properties of Carbon Film Formed by Ion Beam Enhanced Deposition}

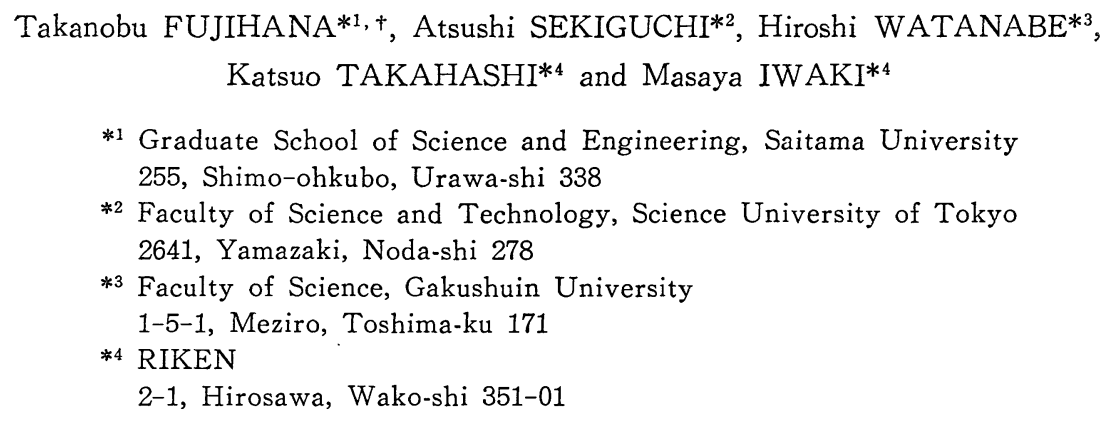

(Received December 19, 1990)

\begin{abstract}
A study has been made of mechanical and electrochemical properties of carbon films on pure iron sheets formed by ion beam enhanced deposition (IBED). The IBED carbon film was formed by implantation of $100 \mathrm{keV}-{ }^{12} \mathrm{C}^{+}$ions up to a dose of $10^{18} \mathrm{ions} / \mathrm{cm}^{2}$ in a fluorocarbon atomosphere. The results showed an increase in surface hardness, and distinct reductions in friction coefficient, wear volume and anodic dissolution of iron. The mechanical and electrochemical properties are discussed with respect to the composition and structure analyzed by XPS, XRD and laser Raman spectroscopy. In conclusion, IBED with $\mathrm{C}^{+}$beam in fluorocarbon atomosphere is a useful technique for formation of the solid lubricating carbon film with high durability.
\end{abstract}

\section{1.はじめに}

炭素は, ダィヤモンド, 黒鈆, 無定形炭素などの構造 を持ち, その構造により光透過性, 電気伝導度, 硬さ, 摩擦, 摩耗, 化学的安定性など著しく異なった特性を持 っている。ダイヤモンドは, 現存する物質の中で最む硬

†本籍(株)新技術研究所, Advanced Technology Inc. 个245 神奈川県横浜市戸塚区名瀬町 84

84, Nase-machi, Totsuka-ku, Yokohama-shi 245
いことから，装飾品としてだけでなく，研削ホイール， 切削ダイスなどの工具類に利用されている1”。黒鉛は, 導電性, 潤滑性に富んだ層状結晶鉣物で, 固体, 粉体, 分散体あるいは非晶質炭素との複合材として, 電極材, 潤滑離型剤，およびすべり軸受けなどの潤滑機構部品な ど広範な用途に用いられている2。。最近では，てのダイ ヤモンド，黒鉛をはじめとして，非晶質炭素あるいは複 合炭化物などの炭素系薄膜の合成に関する研究と, その 応用の探索が行われている 
近年，半導体素子作製のための不純物添加法として用 いられてきたイオン注入法4) を, 金属, セラミックスな ぞの固体材料表層の改質技術として利用する試みがなさ れている5,6)。なかでも，イオン注入を施した鉄鋼材料 表層の機械的 ${ }^{7)}$, 電気化学的性質 ${ }^{8}$ 亿関する研究におい て, 注入された炭素, あるいは注入中にノックオンドー ピングにより残留ガスから混入する炭素が，その表層特 性の改質・改善に重要な役割を果たすととが指摘されて いる。我々屯, 純鉄への高濃度までの炭素イオン注入に よる埋め込み炭化鉄および炭素層の形成が，その電気化 学的性質の改質（耐食性の改善）に有効であることを報 告した ${ }^{9)}$ 。

しかし，イオン注入法は，多種にわたるイオンビーム の発生, 多量注入のための大電流化などの課題を抱え, また, 改質層の深さがイオンの飛程により制限されると いう欠点むある。このような欠点を補う目的で, 薄膜形 成中あるいは薄膜を通してイオン注入を行ういわゆる イオンビームミキシング法が開発された。この技術のト ライボロジー分野への応用として，固体㵎滑剤である $\mathrm{WS}_{2}$ 薄膜 ${ }^{10)}$ や $\mathrm{MoS}_{2}$ 薄膜 ${ }^{11}$ の基板との密着性改善や結 晶性の制御などが試みられてきた。また，イオン注入と 真空蒸着を同時に行うイオンビーム促進成膜 (IBED) 法 (研究者により Dynamical mixing, IVD などとも呼ば れる）屯考案され， $\mathrm{TiN}^{12)}, \mathrm{c}-\mathrm{BN}^{13)}$ などの高硬度薄膜 の形成が試みられている。最近では, 炭素材の優れた 潤滑特性を利用するため, シリコーン油蒸着と窒素注 入 $^{14,15)}$ あるいはアルゴン注入 ${ }^{16)}$ の併用による炭素質薄膜 の形成も試みられている。てのシリコーン油を用いた成 膜は，イオン注入中の (カスケード) 衝突による原子の 混合を利用したものであり，イオンビームを補助的な役 割で使用していることからイオンビームアシスト蒸着 (IBAD) と呼ばれている16)。

我々は，熱源を必要とせず流量制御が容易な低沸点炭 化水素化合物とイオン注入との併用による炭素質薄膜の 形成を試みてきた。こてでは，フロンガス雾团気 (1.33 $\left.\times 10^{-4} \mathrm{~Pa}\right)$ 中での炭素イオン注入により形成した炭素薄 膜の特性について報告する。炭素薄膜形成のための注入 イオン種として, 多量注入によって鉄表層の耐食性が著 しく改善でき，しかも形成される膜の主成分となる炭素 イオンを選んだ。乙の意味から，まさにイオンビーム促 進成膜法と呼ぶことができる。純鉄基板上へ形成した炭 素薄膜の組成・構造を, X線光電子分光法, X線回折法 およびレーザーラマン分光法により分析した。また，硬 さ, 摩擦摩耗特性, 電気化学的特性を調べ, 組成・構造 との関係を検討した。

\section{2. 実験}

\section{1 基板}

基板材料には， $1 \mathrm{~mm}$ 厚の多結晶純鉄（純度 $99.9 \%$ ） を用いた。基板表面は，機械的粗研摩および平均粒径 $0.5 \mu \mathrm{m}$ のアルミナ懸濁液を用いたバフ研摩により鏡面 に仕上げた。成膜前にアセトンおよびトリクロロエチレ ン中で超音波洗浄を施した。

\section{2 イオンビーム促進成膜}

イオン注入装置の注入室内を $6.65 \times 10^{-5} \mathrm{~Pa}$ まで真空 排気し, 分圧 $1.33 \times 10^{-4} \mathrm{~Pa}$ のフロン 113 (トリクロロ トリフルオロエタン, $\left.\mathrm{CCl}_{2} \mathrm{~F}-\mathrm{CClF}_{2}\right)$ を導入した。この 状態で, 注入エネルギー $100 \mathrm{keV}$, 注入量 $5 \times 10^{16} \sim 1 \times$ $10^{18} \mathrm{C}^{+} / \mathrm{cm}^{2}$, イオンビーム電流密度約 $10 \mu \mathrm{A} / \mathrm{cm}^{2}$ の条 件で炭素イオン注入を行った。注入 (成膜) 中は試料ホ ルダーをフロン冷却した。

\subsection{X線光電子分光分析 (XPS)}

作成した各試料の梁さ方向組成分布の測定は, Ar ス パッタリング（加速電圧 $2 \mathrm{kV}$ ）を併用したXPSにより 行った。X線は $\mathrm{Al} \mathrm{K} \alpha(15 \mathrm{kV}, 20 \mathrm{~mA})$ 線を用いた。 構成元素の原子濃度は, 各スパッ夕時間における $\mathrm{Fe}_{2 \mathrm{p}}$, $\mathrm{C}_{1 \mathrm{~s}}, \mathrm{O}_{1 \mathrm{~s}}$ のピーク強度を感度係数により補正し, 総量が $100 \%$ となるように規格化した。炭素の結合状態は $\mathrm{C}_{1 \mathrm{~s}}$ スペクトルをピーク分離することにより調べた。分離に 当たって， $\mathrm{C}_{1 \mathrm{~s}}$ 結合ピークエネルギーを炭化鉄 $(\mathrm{C}-\mathrm{Fe})$ 成分に対し $283.0 \pm 0.2$, 炭素 (C-C) 成分に対し 284.1 \pm 0.1 , 酸化物 $(\mathrm{C}-\mathrm{O})$ 成分に対し $286.0 \pm 0.2 \mathrm{eV}$ とし, 各々ガウス分布を仅定した。炭化水素 $(\mathrm{C}-\mathrm{H})$ 成分は, 炭素 (C-C) 成分との分離が困難であるためてれに含め た。

\section{$2.4 \mathrm{X}$ 線回折 (XRD)}

薄膜解析用ゴニオメーターを用いた XRD により, 各 試料表層の構造同定を試みた。 $\mathrm{Cu} \mathrm{K} \alpha(40 \mathrm{kV}, 40 \mathrm{~mA})$ 線を, 同一平面内を回転する試料の試料面から 5 度の角 度で入射し, 回折角を 70 度から 30 度まで掃引すること により回折パターンを得た。得られた回折ピーク位置と JCPDS (Joint Committee on Powder Diffraction Standard）カードとの照合により構造を同定した。

\section{5 ラマン分光分析}

炭素構造の同定にはレーザーラマン分光法を用いた。 励起光源として波長 $514.5 \mathrm{~nm}$, 出力 $100 \mathrm{~mW}$ の $\mathrm{Ar}$ イ オンレーザーを用いた。試料上の光径は $200 \mu \mathrm{m}$ とし た。分光器は JOBIN YVON 製ダブルモノクロメータ 一 U-1000を用い,スリット幅は $1 \mathrm{~mm}$ とした。測定 は，大気中，室温で後方散乱法にて行った。 


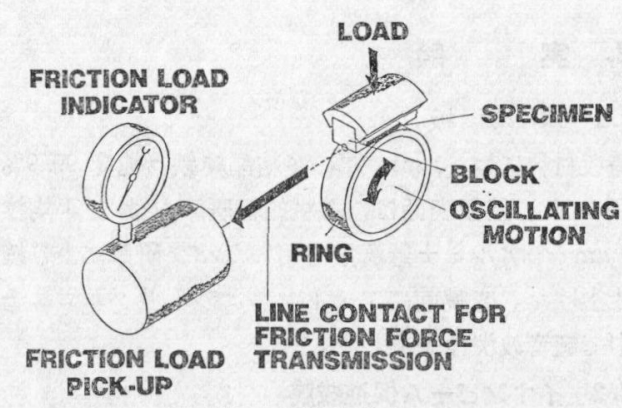

Fig. 1 Schematic drawing of Falex ring and block friction test in an oscillating motion.

\section{6 硬さ測 定}

各試料の表面硬さはヌープダイヤモンド压子を用い た微小硬度計を用いて測定した。测定荷重は $2 \mathrm{gf}$ およ び $5 \mathrm{gf}$ とた。測定点は各試料 7 点以上とし，加圧時 間 $10 \mathrm{~s}$ でつけた圧痕の対角線長さを測定することによ り硬さを求めた。

\section{7 摩擦摩耗測定}

摩擦摩耗特性は, Falex ring and block 摩擦試験機 を用いて調べた。Fig. 1 亿試験装置の概略を示す。作 成した試料をブロック (Falex type H-30) に固定し， 軸受鋼 (SAE 4620) で作られたリング（外径 $35 \mathrm{~mm}$, Falex type S-25) と接触させた。試験は, 大気中, 室 温, 無润滑剂下で行った。荷重 $1 \mathrm{kgf}$, リング摺動角 90 度, 摺動周期 $120 \mathrm{rpm}$ にて繰り返し摺動し, 摩擦力 之摺動回数の関係を調べた。測定した摩擦力から摩擦係 数を求め, 摩擦試験後の摩擦痕幅より摩耗特性を評価し た。

\section{8 電気化学的測定}

電気化学的性質の評価は, 3 電極式電解セルを用いた サイクリックボルタムメトリー $(\mathrm{CVM})^{17)}$ にて行った。 白金電極を対極, 各試料を作用電極, 飽和カロメル電極 を基準電極に用いた。電解液は, $0.5 \mathrm{~mol} / \mathrm{dm}^{3}$ 酷酸一酢 酸ナトリウム緩衝溶液 ( $\mathrm{pH}$ 5.0) を用いた。基準電極に 対する作用 (試料) 電極電位 $-0.7 \mathrm{~V}$ から $+1.0 \mathrm{~V}$ の 間を, 掃引速度 $50 \mathrm{mV} / \mathrm{s}$ にて繰り返し掃引するととに よりボルタモグラムを測定し, 掃引回数と鉄のアノード 溶出電流の関係を求めた。

\section{3. 結果および考察}

\section{1 組成・構造}

\section{1 .1 深さ方向濃度分布}

Fig. 2 亿, XPS ナロースキャンより求めた炭素膜一 鉄中の炭素 $\left(\mathrm{C}_{1 \mathrm{~s}}\right)$, 鉄 $\left(\mathrm{Fe}_{2 \mathrm{p}}\right)$ および酸素 $\left(\mathrm{O}_{1 \mathrm{~s}}\right)$ の深さ方 向濃度分布を示す。注入量 $1 \times 10^{18} \mathrm{C}^{+} / \mathrm{cm}^{2}$ 試料におけ るスパッタ時間 $30 \mathrm{~min}$ までの XPS ワイドスキャン測

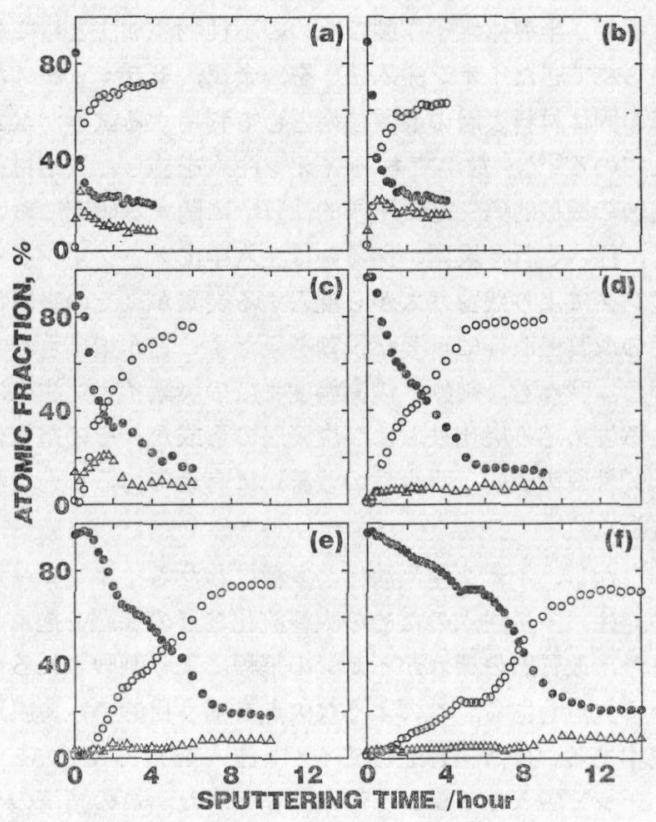

Fig. 2 Atomic fraction depth profiles of $\mathrm{C}(\bullet)$, $\mathrm{Fe}(O)$ and $O(\triangle)$ in carbon films on iron formed by IBED with various $\mathrm{C}^{+}$-doses, measured by XPS. (a) 0.5 , (b) 1.0 , (c) 2. 5, (d) 5.0 , (e ) 7.5 , (f) $10 \times 10^{17} \mathrm{C}^{+} / \mathrm{cm}^{2}$.

定の結果, フロン $113\left(\mathrm{CCl}_{2} \mathrm{~F}-\mathrm{CClF}_{2}\right)$ 中の $\mathrm{Cl}$ および Fの存在が認められなかったため，XPS ナロースキャ ンによるてれらの深さ方向分布の測定は行っていない。

また, 注入量 $7.5 \times 10^{17} \mathrm{C}^{+} / \mathrm{cm}^{2}$ 試料の深さ方向濃度 分布測定後, 表面粗さ計を用いてスパッタ痕の形状測定 を行ったとてろ,その深さは約 $800 \mathrm{~nm}$ であった。この 結果からは, XPS 測定中のスパッタ速度は約 $80 \mathrm{~nm} / \mathrm{h}$ と予想されるが, 組成変化に伴うスパッ夕速度の変化が 把握できていないため, 深さに対応する図の横軸はスパ ッタ時間で示した。

図より, 注入量の増加に伴う炭素膜厚の增加が認めら れる。一方, それぞれの試料における最終スパッ夕時間 でさえ，約 20\% の炭素と約 10\% の酸素が見られる。 これらは炭素注入のみの鉄基板中9'，あるいは窒素注入 したクロム基板中 ${ }^{18)}$ であ見られるととから，XPS 測定 中に試料表面に吸着した残留ガスによるバックグラウン ドであると考えられる。とのため, 注太量 $1 \times 10^{17} \mathrm{C}^{+} /$ $\mathrm{cm}^{2}$ 以下の低注入量試料では, 基板内部の明確な炭素分 布は得られていない。また注入量 $2.5 \times 10^{17} \mathrm{C}^{+} / \mathrm{cm}^{2}$ 以 下の試料では, 表面近傍に酸素の存在が認められ, 注入 量の増加で消失している。

高注入量試料では, 注入およびノックオンドーピング された炭素の存在により，PVD などでの成膜で見られ 
る膜一基板間の明確な境界は見られない。また, 注入量 $1 \times 10^{18} \mathrm{C}^{+} / \mathrm{cm}^{2}$ で形成した最大膜厚の試料でさえ, 基板 の鉄原子がほぼ表面にまで存在する。これは，成膜中に 膜-基板間で双方の原子混合が起とっているととを示し ている。この結果は, 炭素イオン注入によるイオンビー 么促進成膜法が，膜一基板間に鋭い界面のない，すなわ ち密着性の高い炭素薄膜の形成に有効であるととを示し ている。

注入量 $2.5 \times 10^{17} \mathrm{C}^{+} / \mathrm{cm}^{2}$ 以下の試料で認められた表 面近傍の酸素は，注入 (成膜) 前に形成された鉄の酸化 物で, 注入量の増加に伴う消失はイオンビーム照射によ る離脱であると思われる。イオンビーム照射中にガス成 分が離脱する現象は，高分子フィルムへのイオン注入に よる表層の炭化現象として観測されている。ポリイミド

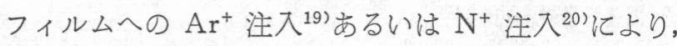
表層から $\mathrm{N} ， \mathrm{O}$ が離脱するととが報告され，ポリメチル メタアクリレートおよびポリ塩化ビニルへの $\mathrm{Ar}^{+}$注入 では，それぞれ $\mathrm{N} と \mathrm{O}, \mathrm{Cl}$ の離脱が報告されている ${ }^{21}$ 。 本研究におけるフロン中の $\mathrm{Cl}$ と $\mathrm{F}$ の離脱む, 乙れと同 様の現象により注入中に引き起とされたものと考えられ る。また，鉄基板表層からの酸素の離脱は，イオンビー ム照射により鉄との結合を切断された酸素が $\mathrm{O}_{2}$ とし て, あるいは C と結合し $\mathrm{CO}_{2}$ として離脱したものと考 えられる。形成した炭素膜は，乙のようなイオン注入中 のガス成分の離脱と, 基板との界面混合によって, ほと んどCと $\mathrm{Fe}$ で構成された膜となっていると推察でき る。

Fig. 3 亿, 注入量 $5 \times 10^{17} \mathrm{C}^{+} / \mathrm{cm}^{2}$ で作成した武料の スパッタ時間 $1 \mathrm{~h}$ および $3 \mathrm{~h}$ における $\mathrm{C}_{1 \mathrm{~s}}$ スペクトル を示す。C-O 結合成分は, 本試料の最終スパッ夕時間の $9 \mathrm{~h}$ であ認められることから，前述したように分析中に 吸着した残留ガス成分であると考えられる。表面近傍の スパッタ時間 $1 \mathrm{~h}$ のスペクトルにおいてむ、C-C 結合 成分に加えて C-Fe 結合成分が認められ，その比率 (C$\mathrm{Fe}) /(\mathrm{C}-\mathrm{C})$ は約 $1 / 6$ となっている。一方, 膜-基板界面近 傍の深さに相当するスパッタ時間 $3 \mathrm{~h}$ では, C-Fe 結合 成分の比率は, $(\mathrm{C}-\mathrm{Fe}) /(\mathrm{C}-\mathrm{C}) \fallingdotseq 1 / 2$ となっている。また, 両者の C-Fe 結合のピークエネルギーに若干 $(0.4 \mathrm{eV})$ の差が見られる。これは, 各々の深さでの炭化鉄の結合 状態が異なることを示しており，それぞれの炭化鉄構造 が異なる可能性を示唆している。この解明のためには, 断面 TEM・TED 観察などの深さ方向の詳細な構造解 析が必要である。

以上の結果より, 本イオンビーム促進成膜法によって 形成した炭素薄膜が， C-C 結合と C-Fe 結合成分で構 成されているととが分かった。
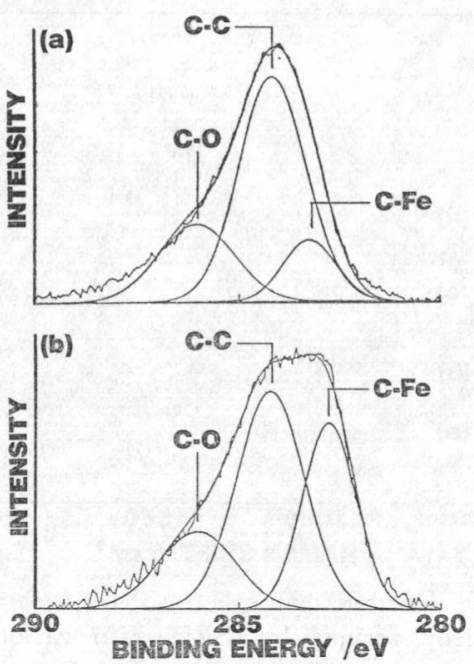

Fig. 3 Resolved binding energy spectra of $\mathrm{C}_{1 \mathrm{~s}}$ for the carbon film on iron formed by IBED with a dose of $5 \times 10^{17} \mathrm{C}^{+} / \mathrm{cm}^{2}$, after 1 (a) and $3(b)$ hours of sputtering time.

\section{1 .2 構造}

Fig. 4 亿各成膜試料の XRD パターンを示す。鉄基 板の $\alpha-\mathrm{Fe}$ からの回折ピーク 以外に, 多くの回折ピー クが見られる。注入量 $1 \times 10^{17} \mathrm{C}^{+} / \mathrm{cm}^{2}$ 以下の試料では

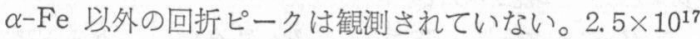

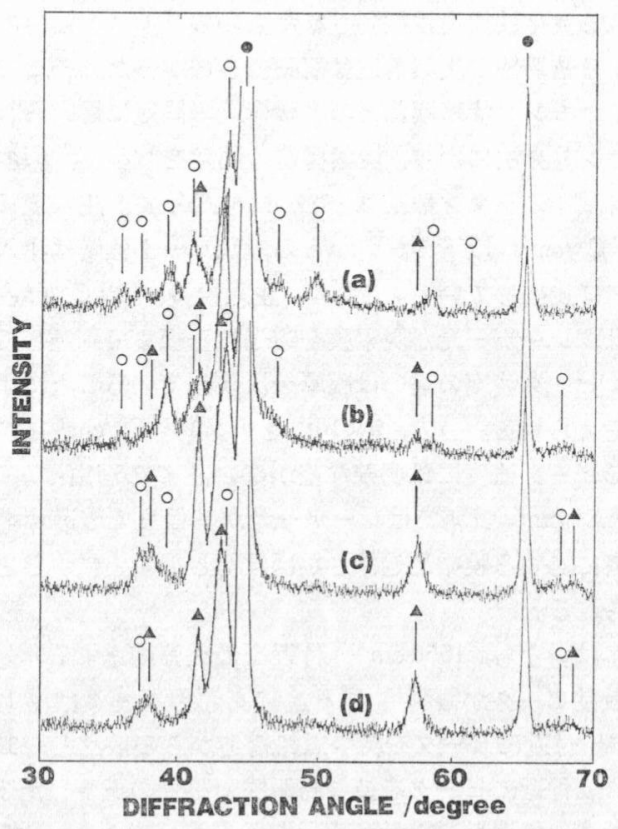

Fig. 4 XRD patterns of the carbon films on iron formed by IBED with various $\mathrm{C}^{+}$-doses. (a) 2.5 , (b) 5.0 , (c) 7.5 , (d) $10 \times 10^{17} \mathrm{C}^{+} / \mathrm{cm}^{2}$. - $\mathrm{Fe}, \bigcirc \mathrm{Fe}_{2 .} \mathrm{C}, \Delta \mathrm{Fe}_{2} \mathrm{C}$. 


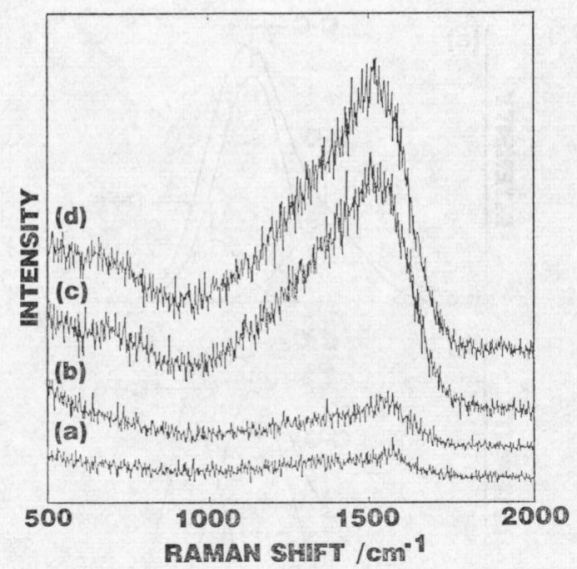

Fig. 5 Laser Raman spectra of the carbon films on iron formed by IBED with various $\mathrm{C}^{+}-$ doses. (a ) 0.5 , (b) 1.0 , (c) 5.0 , (d) 10 $\times 10^{17} \mathrm{C}^{+} / \mathrm{cm}^{2}$.

$\mathrm{C}^{+} / \mathrm{cm}^{2}$ で見られる明瞭な回折ピーク○は単結晶 $\mathrm{Fe}_{2 .} \mathrm{C}$ 構造からの回折位置に一致する。これらの回折ピークと 共に, 斜方晶 $\mathrm{Fe}_{2} \mathrm{C}$ あるいは単斜晶 $\mathrm{Fe}_{2} \mathrm{C}$ 構造からと推 定される弱い回折 $\mathbf{\Delta}$ が観測される。 $5 \times 10^{17} \mathrm{C}^{+} / \mathrm{cm}^{2}$ 試料 では $\mathrm{Fe}_{2} \mathrm{C}$ 構造からのピーク強度が増加し, さらに注入 量を増した試料では， $\mathrm{Fe}_{2.5} \mathrm{C}$ 構造からのピーク数が減 少する傾向が認められる。

XRD 測定では, XPS での C-Fe 結合に対応すると思 われる炭化鉄構造は観測されたものの，C-C 結合に対 応する結晶性の炭素構造は観測できなかった。そこで， ダイヤモンド状薄膜などの炭素構造の同定に用いられる ラマン分光法により，炭素構造の同定を試みた。Fig.5 に各試料のラマン散乱スペクトルを示す。注入量 $5 \times$ $10^{17} \mathrm{C}^{+} / \mathrm{cm}^{2}$ 以下の試料からの散乱ピーク強度は注入量 にほぼ比例している。これは, 注入量 $5 \times 10^{17} \mathrm{C}^{+} / \mathrm{cm}^{2}$ ま では, レーザー光が炭素膜を透過し基板まで到達してお り，ピーク強度の違いは膜厚を反映していることによる と考えられる。一方, $5 \times 10^{17}$ と $1 \times 10^{18} \mathrm{C}^{+} / \mathrm{cm}^{2}$ 試料か らのピーク強度には明確な差がない。この理由は, 1× $10^{18} \mathrm{C}^{+} / \mathrm{cm}^{2}$ 試料ではレーザー光が基板まで透過せず，

両者に対する膜中透過深さがほぼ等しいととによると考 えられる。

各試料とす $1550 \mathrm{~cm}^{-1}$ 付近を最大強度とする非対象 な散乱ピークが観測される。との散乱ピークは, 1580 $\mathrm{cm}^{-1}$ 付近にピークを持つ黒鉛構造からの散乱と, 1360 $\mathrm{cm}^{-1}$ 付近にピークを持つ局所的対称性の低下した不規 則性黒鉛構造からの散乱 ${ }^{22,23)}$ を含んだピークで, 非晶質 炭素膜 ${ }^{24)}$ あるいはイオン注入により非晶質化したガラス

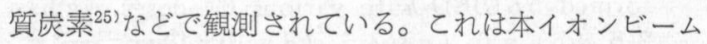
促進成膜法で形成した炭素薄膜が，非晶質炭素構造を持
つことを示している。XPS 測定で観測された C-C 結 合が，この非晶質炭素に起因するすのであることが分か る。

組成・構造解析の結果，形成した炭素膜が，非晶質炭 素と炭化鉄により構成されることが分かった。加えて, XRD 測定において観測された斜方晶・単斜晶構造の $\mathrm{Fe}_{2} \mathrm{C}$ および $\mathrm{Fe}_{2 .} \mathrm{C}$ が，通常 $230^{\circ} \mathrm{C}$ 以下の温度で合成 される準安定炭化鉄である ${ }^{26)} と$ とか，本イオンビーム 促進成膜法がこの温度以下の低温プロセスでの成膜法で あることが裏付りられる。また，イオン注入によるガ ラス質炭素の非晶質化がその耐摩耗性の改善に有効であ $ろ^{25)}$ こかか, 同様の非晶質炭素構造を持つ本薄膜も摩 耗に対して高い抵抗力を持つととが予想される。

\section{2 表層特性}

\section{2 .1 機械的特性}

Fig. 6 そ，各試料のヌープ硬さを示す。測定荷重は $2 \mathrm{gf}$ および $5 \mathrm{gf}$ である。横軸は試料の注入量で示した。 表層硬さは注入量 (膜厚) の増加に従い増加する。 $2 \mathrm{gf}$ 測定での最大注入量 (最大膜厚) 試料におりる硬さは, 基板の約 2 倍に達している。圧子侵入深さの浅い $2 \mathrm{gf}$ での測定でより高い值を示すととから，表面側の硬さが より高いことが分かる。

ダイヤモンド圧子を試料表面に押し込み, 試料面に残 った永久くぼみから硬さを得る測定では，圧子先端到達 深さの十数倍深い領域までの影響を受けることが知られ ている。このため, 膜厚が非常に薄い場合には, 薄膜層 のみの硬さ測定は困難である。本実験における測定硬さ は，各々の表面硬さを定性的に表したもので，形成した 炭素膜本来の硬さは, 測定值よりもかなり高いものと考 えられる。

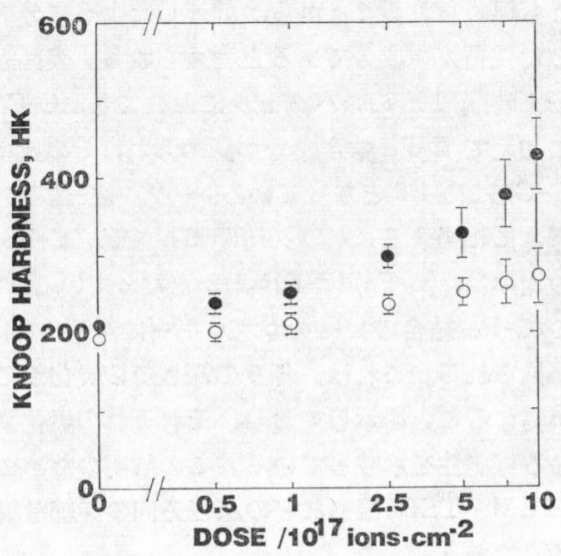

Fig. 6 Knoop hardnesses of pure iron and carbon films on iron formed by IBED, as a function of $\mathrm{C}^{+}$-dose. The applied loads were 2 (๑) and 5 (O) gf. 


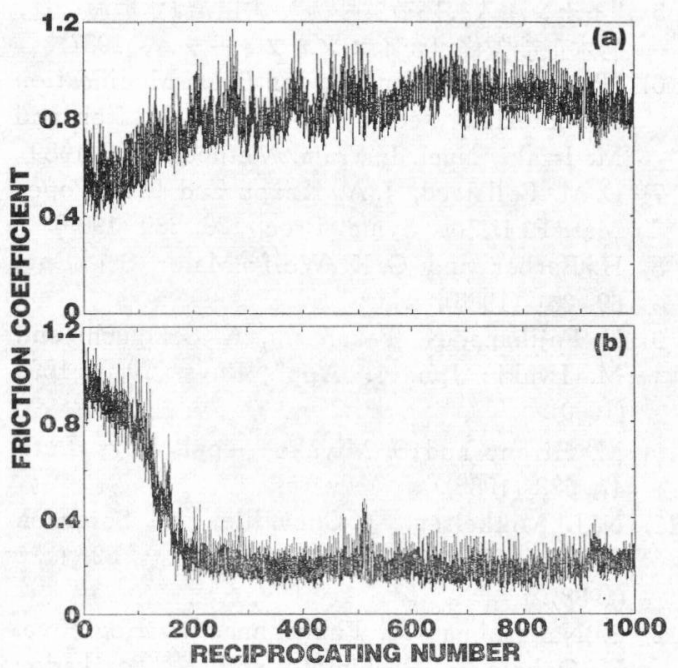

Fig. 7 Relationship between the friction coefficients and reciprocating cycles of pure iron (a) and the carbon film on iron formed by IBED with a dose of $1 \times 10^{18} \mathrm{C}^{+} / \mathrm{cm}^{2}$ (b).

Fig. 7 に, Falex ring and block 試験による摺動回 数と摩擦係数の関係を示す。摺動回数初期（摺動回数約 300 回まで）における純鉄と軸受鋼リングとの摩擦係数 は搐動回数の増加に伴い増加し，その後 0.7〜1.0 で推 移する。初期摩擦が鉄表面あるいはリング表面の酸化物 の摩擦であり，摺動回数の増加に伴い徐々に酸化物層が 削り取られ, 鉄-鋼の摩擦に変化したものと推察できる。

一方, 注入量 $1 \times 10^{18} \mathrm{C}^{+} / \mathrm{cm}^{2}$ の炭素膜とリングと の摩擦係数は，摩擦初期（約 150 回まで）において高 く，その後低下する。この現象は，固体潤滑剂の $\mathrm{MoS}_{2}$ 被覆などにおけるなじみ過程 ${ }^{2)}$ に類似している。初期の 高摩擦係数領域が, 雾囲気から吸着した不純物による結 合力の高い，すなわち高せん断強度表面の形成によるも ので, 低摩擦係数領域への移行は, 摩耗による吸着層の 除去, 摩擦熱の発生による不純物の離脱などにより本来 の膜-鋼の摩擦に変化したとと，あるいは膜自身が低せ ん断強度構造へ変化したことなどが考えられるが，この 解明のためにはさらに検討を要する。ともかく，低摩擦 係数領域での摩擦係数は $0.2 \pm 0.1$ とかなり低い。形成 した炭素薄膜が高潤滑性 (低摩擦係数) 薄膜となってい るととを示している。

Fig. 8 に, 摩擦試験（摺動回数 1000 回）後の摩擦痕 の写真を示す。炭素薄膜の摩擦痕幅は未処理の $1 / 2$ 以下 となっている。摩擦係数の低下と共に摩耗量が減少した ことが分かる。これらの結果は，イオンビーム促進成膜 法により形成した炭素薄膜が，低凝着力の高耐久性潤滑 薄膜となっていることを示している。
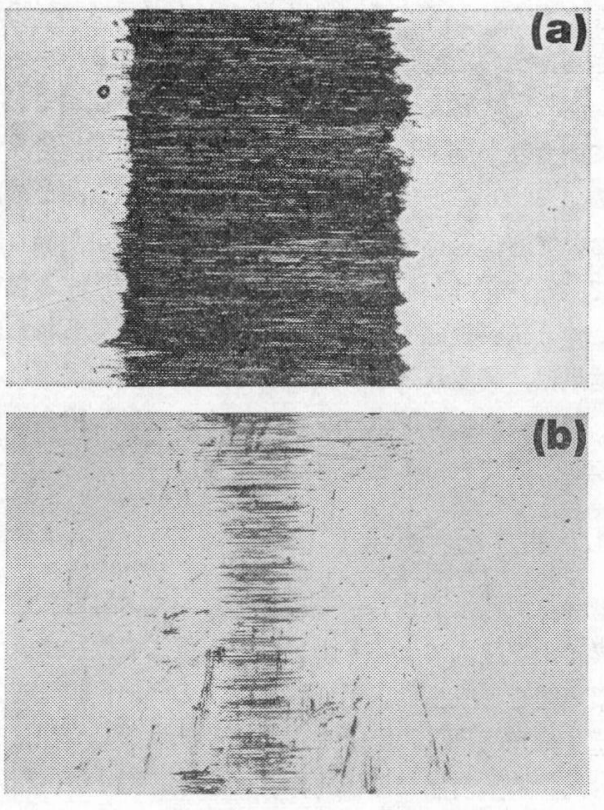

\section{$1 \mathrm{~mm}$}

Fig. 8 Wear scars of pure iron (a) and the carbon film on iron formed by IBED with a dose of $1 \times 10^{18} \mathrm{C}^{+} / \mathrm{cm}^{2}$ (b), observed after 1000 reciprocating cycles of the friction test.

\section{2 .2 電気化学的特性}

Fig. 9 に, CVM 测定による各試料の鉄のピークアノ ード溶出電流と電位掃引回数の関係を示す。比較のため 純鉄の測定結果む示した。

電位掃引回数 20 回でのピークアノード溶出電流を比

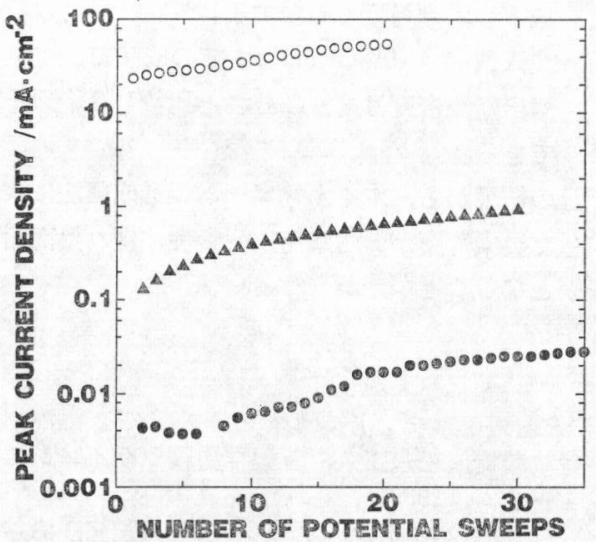

Fig. 9 Relations between anodic dissolution peak current density and potential sweep cycles measured by the cyclic voltammetry for pure iron and carbon films on iron formed by IBED with various $\mathrm{C}^{+}$- doses. $\bigcirc$ pure iron, A 1. $0,10 \times 10^{17} \mathrm{C}^{+} / \mathrm{cm}^{2}$. 
較した場合, 膜厚の薄い注入量 $1 \times 10^{17} \mathrm{C}^{+} / \mathrm{cm}^{2}$ の試料 でさえ，その電流密度は純鉄のそれに比べ 2 标小さい。 最大注入量 (最大膜厚) の $1 \times 10^{18} \mathrm{C}^{+} / \mathrm{cm}^{2}$ 試料では, さ らに耐食性が向上し, ピークアノード溶出電流密度は純 鉄の $1 / 3000$ 亿まで低下する。しかしながら，ての試料 においても, 電位掃引回数の増加に従い溶出が繰り返さ れている。CVM 测定後の SEM 観察では, 注入量の增 加に伴う試料表面のピンホール数の減少が見られた。て の結果は, 高注入量までのイオンビーム促進成膜によっ て, 薄膜表面のピンホールの著しく少ない高耐食性炭素 薄膜が形成できることを示している。

\section{4. ま と め}

低沸点炭化水素化合物であるフロンガス雾囲気中での 炭素イオン注入によるイオンビーム促進成膜法により, 炭素薄膜を形成した。形成した薄膜の組成, 構造をX線 光電子分光法, X線回折法, およびラマン分光法により 調べた。薄膜表層の機械的特性として, 微小硬度計を用 いてヌープ硬さを, Falex ring and block 試験機を用い て摩擦摩耗特性を評価した。また，酷酸一酢酸ナトリウ

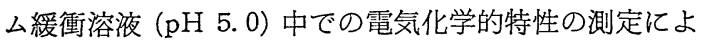
り耐食性を評価した。以下に結果をまとめる。

1) 本イオンビーム促進成膜法により形成した薄膜 は，基板との鋭い界面のない，すなわち密着性の 高い膜となる。

2）形成した薄膜中の炭素は, 非晶質炭素と炭化鉄成 分により構成される。

3）薄膜の硬さは，純鉄基板の 2 倍以上に達する。

4) 本炭素薄膜の被覆により, 摩擦係数は約 0.2 まで 低下し, 摩耗量も減少する。

5) 注入量 $1 \times 10^{18} \mathrm{C}^{+} / \mathrm{cm}^{2}$ までの成膜で, アノード 溶出電流密度は純鉄のそれと比較し 3 桁以上低減 できる。

以上の結果から, 本イオンビーム促進成膜法によって 形成した炭素薄膜が, 耐摩耗, 而食性に優れた高耐久性 潤滑膜となることが分かった。

\section{文献}

1）“人造ダイヤモンド技術ハンドブック”, 瀬高信雄 難波義捷, 松永正久, 若梘雅男編（サイエンスフ ォーラム, 1989).

2) “固体潤滑ハンドブック”, 松永正久監修, 津谷裕 子編 (幸書房, 1978).

3）犬塚直夫: “ダイヤモンド薄膜”，日本表面科学会 編, 表面・薄膜分子設計シリーズ 10 (共立出版, 1990).

4）難波 進：“イオン注入技術”, エレクトロニクス 技術全書8（工業調查会，1975）.
5）“イオン注入表層改質技術”, 吉田清太, 難波 進, 岩木正哉監修（サイエンスフォーラム, 1987).

6) "Proc. 6th Int. Conf. on Ion Beam Modification of Materials", ed. by S. Namba, N. Itoh and M. Iwaki, Nucl. Instrum. Methods B 39 (1989).

7) D. M. Follstaed, J. A. Knapp and L. E. Pope: Mat. Res. Soc. Symp. Proc. 128, 389 (1989).

8) H. Ferber and G. K. Wolf : Mater. Sci. Eng. 69, 261 (1985).

9) T. Fujihana, K. Takahashi, A. Sekiguchi and M. Iwaki : Jpn. J. Appl. Phys. 29, L 1895 (1990).

10) M. Hirano and S. Miyake: Appl. Phys. Lett. 47, 683 (1985).

11) N. J. Mikkelsen, J. Chevallier, G. Sorensen and C. A. Straede: Appl. Phys. Lett. 52, 1130 (1988).

12) S. Nakashima, M. Fukushima, M. Haginoya, K. Oohata, I. Hashimoto and K. Terakado: Mater. Sci. Eng. A 115, 197 (1989).

13) 田辺信夫, 林 常昭, 岩木正哉: 第六回イオン注 入表層処理シンポジゥム予稿集（イオン注入表層 処理研究会, 1990) p. 103.

14) M. Braun: Nucl. Instrum. Methods B 39, 554 (1989).

15) M. Braun: Nucl. Instrum. Methods B 39, 556 (1989).

16) T. Hioki : Proc. 2nd Japan-Sino Symp. on Ion Surface Optimization of Materials (Jpn. Soc. of Surface Layer Modification by Ion Implantation, 1989) p. 79.

17) K. Takahashi, Y. Okabe and M. Iwaki : Nucl. Instrum. Methods 182/183, 1009 (1981).

18) O. Nishimura, K. Yabe and M. Iwaki: J. Electron Spectrosc. Rela. Phenom. 49, 335 (1989).

19) K. Yoshida and M. Iwaki: Nucl. Instrum. Methods B 19/20, 878 (1987).

20) T. Hioki, S. Noda, M. Sugiura, M. Kakeno, K. Yamada and J. Kawamoto: Appl. Phys. Lett. 43, 30 (1983).

21) T. Venkatesan, S. R. Forrest, M. L. Kaplan, C. A. Murray, P. H. Schmidt and B. J. Wilkens : J. Appl. Phys. 54, 3150 (1983).

22) F. Tuinstra and J. L. Koenig: J. Chem. Phys. 53, 1126 (1970).

23) B. S. Elman, M. S. Dresselhaus, G. Dresselhaus, E. W. Maby and H. Mazurek: Phys. Rev. B 24, 1024 (1981).

24) S. A. Solin and R. J. Koblisaka: Proc. 5th Int. Conf. on Amorph. Liq. Semicond. 2, 1251 (1974).

25) M. Iwaki, K. Takahashi and A. Sekiguchi : J. Mater. Res. 5, 2562 (1990).

26) "Metals Handbook", 8th edition, vol. 8, (American Society for Metals, 1973) p. 277. 